\section{Mykoplasma hominis}

\author{
W. Stöcker \\ Euroimmun Medizinische Labordiagnostika AG, Lübeck, \\ Deutschland
}

\section{Englischer Begriff Mycoplasma hominis}

Beschreibung des Erregers Mykoplasmen gehören zu den kleinsten selbstreproduzierenden Bakterien. Sie besitzen keine starre Zellwand (Mureindefizit) und sind daher gegen Zellwand-aktive Antibiotika resistent. Es wurden mehr als 12 Arten der Gattung Mykoplasma beim Menschen gefunden, zu denen auch M. hominis gehört.

Erkrankungen $M$. hominis wird vermehrt bei Urethritis, Zervizitis und Vaginitis gefunden. Gelegentlich verursacht es milde Bakteriämien (z. B. nach Geburten, gynäkologischen Operationen und Aborten), Wundinfekte, Salpingitis, Amnionitis und Infektionen des Neugeborenen. Die Übertragung erfolgt primär über die Geschlechtsorgane.

Analytik Direktnachweis durch Nukleinsäure-Amplifikationsverfahren (z. B. $>$ PCR (Polymerase-Kettenreaktion)). Die Erreger lassen sich auf Pferdeserum-haltigen Spezialkulturen innerhalb von 4Tagen unter anaeroben Bedingungen anzüchten, unter $\mathrm{CO}_{2}$ - und $\mathrm{N}_{2}$-haltigen Gasmischungen.

Serologie: Nachweis von Antikörpern gegen Mykoplasma hominis durch indirekte Immunfluoreszenz ( $\triangleright$ Immunfluoreszenz, indirekte) (Substrat: Mykoplasma-infizierte Kulturzellen) oder $>$ Enzymimmunoassay.
Untersuchungsmaterial - Probenstabilität Direktnachweis und Kultur: Als Untersuchungsmaterial kommen Abstriche oder Sekrete des Urogenitaltrakts infrage. Man verwendet ein Saccharose-Phosphatpuffer-Transportmedium (SP2-Medium). Es sollte gekühlt transportiert und innerhalb von 4 Stunden analysiert werden. Ein schneller Transport ist notwendig, da bereits nach 24 Stunden mit einer Abnahme der Keimzahlen um den Faktor $10 \mathrm{zu}$ rechnen ist.

Serologie: Serum oder Plasma für den Nachweis der Antikörper sind bei $+4{ }^{\circ} \mathrm{C}$ bis zu 2 Wochen lang beständig, bei $-20{ }^{\circ} \mathrm{C}$ über Monate und Jahre hinweg. Zur Tiefkühlkonservierung des IgM kann man den Proben 80 \% gepuffertes Glyzerin beifügen.

Diagnostische Wertigkeit Die Diagnostik beruht auf dem Nachweis hoher Keimzahlen des Erregers im Urogenitaltrakt. Antikörpertests bei Infektionen durch M. hominis haben wegen der weiten Verbreitung des Erregers als Bestandteil der kommensalen Flora eine nur eingeschränkte diagnostische Bedeutung.

\section{Literatur}

Mardh PA (2004) Mycoplasma and Ureaplasma. In: Cohen J, Powderly WG (Hrsg) Infectious diseases, 2. Aufl. Mosby/Elsevier Health Sciences, London, S 2309-2315

Waites KB (2008) Ureaplasma infection. eMedicine: http://www.emedi cine.com/med/topic2340.htm 